International Journal of Social Science and Economic Research

ISSN: $2455-8834$

Volume: 05, Issue: 05 "May 2020"

\title{
EFFECT OF BEHAVIOURAL BIASES ON INVESTMENT DECISIONS FOR INDIVIDUAL INVESTORS AT NAIROBI SECURITIES EXCHANGE
}

\author{
${ }^{1}$ CYNTHIA KARENDI KIVUTI, ${ }^{2}$ DR. ONESMUS MUTUNGA \\ ${ }^{1}$ SCHOOL OF BUSINESS, UNIVERSITY OF NAIROBI, KENYA \\ ${ }^{2}$ LECTURER, SCHOOL OF BUSINESS, UNIVERSITY OF NAIROBI.
}

DOI: 10.46609/IJSSER.2020.v05i05.020 URL: https://doi.org/10.46609/IJSSER.2020.v05i05.020

\begin{abstract}
While investors have traditionally been viewed as rational, with time, some variations from rationality have been experienced and this can be attributed to behavioural biases affecting investors. Investors trade excessively, follow the behaviours of other investors and sell wining stocks while holding onto losing stocks. The researcher aimed to determine the effect of behavioural biases on investment decisions for individual investors at NSE. The target population was individual investors at NSE.A sample of 100 investors was selected for this study and data collected through questionnaires. In the study, descriptive research design was used, as it is good in explaining behaviours and attitudes. Descriptive and inferential statistics were employed in the analysis and STATA 13.0 was used for analysis. Data were expressed in frequencies and percentages and results presented in tables and figures. The relationship between the dependent and independent variable was established using simple regression analysis. Regression diagnostics tests including tests for normality, heteroscedasticity and multicollinearity were carried out to ensure fitness of the model. The researcher did correlation analysis and results indicate there was a significant weak negative correlation between anchoring and investor's percentage returns. $(\mathrm{R}=-0.30, \mathrm{P}=0.03)$. Regression results indicate that anchoring, availability and herding had a significant effect on investment decisions with a $\mathrm{P}$ value of 0.03 for anchoring , 0.04 for availability and 0.04 for herding. Results indicates that investors who have anchoring and availability had lower returns than those without the biases. Those who had herding behaviour experienced better results than those who had no herding behaviour. Other behavioural biases were found to have no significant effect on investor's returns. From the multivariable analysis, $\mathrm{R}^{2}$ results indicate that $27.90 \%$ of the changes in investors returns can be explained by behavioural biases. The other changes in returns, $72.10 \%$ can be explained by other factors not accounted for in this study. F test from ANOVA analysis
\end{abstract}


indicate that there were no big variances in the means. The study concludes that investors experience biases that affect their decisions and thus they should be sensitised on how to carefully analyse the markets and the information available to avoid poor decisions. The study recommends more education on finance topics to increase knowledge in the field.

Keywords: Investment decisions, Individual investors, Nairobi Securities Exchange, Stock Market
ABBREVIATIONS
CDS Central Depository System
CMA Capital Markets Authority
IPO Initial Public Offer
NSE Nairobi Securities Exchange
VIF Variance Inflation Factors

\section{CHAPTER ONE}

INTRODUCTION

\subsection{Background of the Study}

Traditionally, investors were viewed as rational people with the tendency to maximise their returns when making their investment decisions. Over time, investors have been observed to exhibit herding behaviour where they follow actions of people close to them, they dwell on previous performance, sell winning stocks while holding losing stocks and they also trade excessively. Behavioural biases occur when people's psychology and emotions drive them to irrational decisions. Investor decision making on the other hand entails the process through which investors select among alternatives the path that will lead them to achieving optimal perceived utility. Chaudhary (2013) tries to explain why investors behave irrationally by combining behaviour and cognitive psychology with the conventional economic theory. He looks at behavioural biases as the reason for people buying or selling stocks without proper fundamental analysis.

This study is based on the following theories; efficient markets theory, expected utility theory, prospect theory, heuristics theory and modern portfolio theory. According to the expected utility theory, investors make decisions on risky alternatives based on the level of utility they expect from the alternatives (Mongin, 1997). The efficient market theory believes that for markets o be efficient, security prices should be a reflection of all available information (Fama, 1970). 


\section{International Journal of Social Science and Economic Research}

ISSN: $2455-8834$

Volume: 05, Issue: 05 "May 2020"

Kahneman and Tversky (1979) in the prospect theory observed that a good number of investors rely on heuristics and there is prevalence of biases. Heuristics theory looks at the mental states that investors experience while making decisions. There are three heuristics identified as; anchoring, availability and representativeness (Tversky \& Kahneman, 1974). Portfolio theory originated by Markowitz states that investors will select securities which enable them earn highest returns given a certain level of risk (Markowitz, 1952). With behavioural biases however this might not be the case always.

In this study, the researcher mainly considered individual investors at NSE. The NSE is one top Securities Exchange in Africa that offers investors exposure and a trading opportunity by listing equity and debt securities. Individual investors were targeted as they are more vulnerable to biases and those listed at NSE were considered for this study. While many individuals have different ways of investing, those interested in trading at NSE have to open a Central Depository System (CDS) account with their stockbrokers making it easier to define a population for study.

\subsubsection{Behavioural Biases}

Behavioural biases occur when people's decision-making ability is influenced by feelings, emotions and intuition thus they end up making irrational decisions. These biases are factors related to peoples' psychology and feelings which influence the behaviour of investors and the efficiency of the markets. Modern research suggests that investors have several cognitive and psychology errors to deal with which lead to irrational behaviour. Investors therefore end up falling prey of their own behaviour mistakes. Investors either overreact or underreact to events in the stocks market. Some behavioural biases include; herd behaviour, disposition effect, and overconfidence bias. Behavioural biases refer to the effect of psychology on investor choices (Shefrin \& Statman, 2000). Investors who are naive speculators blindly follow crowds and react to the behaviour of other investors in the market to avoid losing profitable opportunities (Lux, 1995).

Behavioural biases occur when the ability to make decisions for investors is affected by feelings and emotions leading them to make irrational choices. According to Barberis and Thaler (2002) behavioural biases comprise of psychology which explains peoples thought process and errors. It also includes limits to arbitrage, which encompasses the ability to identify arbitrage opportunities. Coval and Shumway (2005) document strong evidence for behavioural biases and seeks to investigate their effect on prices. Behavioural biases can be measured by excessive trading, oversubscriptions in some stocks, short investment horizons, too much fear for losses and investing in groups.

\subsubsection{Investor Decision Making}




\section{International Journal of Social Science and Economic Research}

ISSN: $2455-8834$

Volume: 05, Issue: 05 "May 2020"

Decision-making is the process of selecting between a set of alternatives. Investor decision making is a versatile action, imposes kind of an explicit dilemma to the individual, and extends to the environment.Investment decision making is more human than analytical owing to behavioural biases (Virigineni \& Rao, 2017). Virlics (2013) define decision making as a subjective act based on analysis of risk and uncertainties pertaining to the different alternatives. According to him, choice is influenced by expected costs, risk perception, experience and expectations about the future. Lichtenstein and Slovic (1970) define decision making as a man's capability of integrating information into a judgement. More information enables investors to make better investment decisions.

Decision making entails selecting an alternative among many available options (Shunmugathangam, 2017). He defines decision making as a complex process involving several factors and looks at the process as one of the very critical things investors ought to do. He acknowledges that investors make common mistakes like selling too soon as they are influenced by market sentiments. Decision-making is an important process as it is through this process that a course of action is selected. The decision taken by an investor determines whether at the end they gain or lose on their investment. Investors if faced with risky outcomes for different choices will chose the one that maximizes their potential perceived gain from the various possibilities (Neumann \& Morgenstern, 1947).Choices among risky prospects are however not always consistent with utility theory (Kahneman \& Tversky, 1979). Decision making can be measured by the extent to which returns from an investment differ from other comparable choices.

\subsubsection{Behavioural Biases and Investor Decision Making}

Khresna Brahmana, Hooy, and Ahmad (2012) built a conceptual framework that links psychological biases; heuristics, regret and cognitive biases to investors irrational behavior especially day of the week anomaly. Bondt and Thaler (1985) are of the opinion that people overreact to drastic unexpected events. Barber and Odean (2013) believe that, individual investors will be more inclined towards buying attention-seeking stocks as they have trouble in looking for and evaluating the many stocks they can possibly buy. A model developed by Sanglier, Romain, and Flament (1994) supports decisions as a tool used to manage financial portfolios. It assists decision makers in formalizing, testing and analyzing the implication of their strategies and actions in the market. Kahneman and Tversky (1979) found that in making decisions under risk, people sometimes behave irrationally which is inconsistent to the traditional theory. They developed an alternative model, prospect theory which states that people weigh options based on potential gains or losses and not on the final outcome. They described decisions between risky alternatives.

\subsubsection{Individual Investors at Nairobi Securities Exchange}




\section{International Journal of Social Science and Economic Research}

ISSN: $2455-8834$

Volume: 05, Issue: 05 "May 2020"

Individual investors are those that buy in small quantities and may experience challenges in getting funding for their investments. Nairobi Securities Exchange offers a trading platform to investors by having debt and equity securities listed. There were 1,192,331 investors trading in both equity and bonds at Nairobi Securities Exchange as per Capital Markets Authority Q1 2019 Bulleting. These were composed of 1,176,978 local investors, 8,070 foreign individual investors and 7,283 East African Individual investors. For an investor to trade they are required to open a Central Depository System account with their brokers to enable them buy and sell securities. Trading is done in an online platform.

These investors are affected by the level of information available to them and by their investment behaviours. Representativeness bias, anchoring, availability bias and status quo influence the decisions of investors (Onsomu, Kaijage, Aduda, \& Iraya, 2017b). While some investors have good experience in trading at NSE, majority still lack adequate information and are affected by herding behaviour (Aduda, Oduor, \& Onwonga, 2012).Disposition effect, herding and overconfidence greatly influence individual investors at NSE (Nyamute, 2016).

\subsection{Research Problem}

Traditional models in finance held that investors behave rationally. With time behavioural biases have been observed to affect the choices made by investors as they act under the influence of psychology and emotions. These biases hinder the rationality of investors as they cause investors to rely heavily on past performance and occurrences, have poor investment strategies and follow the behavior of other investors. Kafayat (2014) observed that investors with behavioural biases such as self-attribution and overconfidence make irrational decisions that lead to lower returns. Investors have behaviours contrary to modern economic theories as they hold undiversified portfolios, trade frequently and have poor portfolio selection strategies (Barber \& Odean, 2013).

Kenya is a growing economy and has the number of investors applying to be listed increasing. As per the Capital Markets Authority Quarterly Statistical Bulleting Q1 2019, a total of 3,963 new accounts were opened relating to individual investors in the first quarter of 2019 representing a 7.5\% increase compared to Q4 2018 (CMA, 2019). The investors experience scarcity of information while making decisions as the number of investment advisors at NSE remains low despite the growth in investor numbers. Investors at NSE experience biases leading the market to a different direction than expected. This has been evidenced by numerous under or oversubscriptions in IPO's especially the NSE offer which had about 764\% subscription level.

Several scholars have focused on this field and studies have shown individual aspects of behaviour that lead to anomalies and irrational choices by investors. People experience feelings of fear and anticipation, which elicit market sentiments that can drive the market either in a positive or negative way. Chandra (2009) investigated how the experience and competence of 


\section{International Journal of Social Science and Economic Research}

ISSN: $2455-8834$

Volume: 05, Issue: 05 "May 2020"

individual investors affect their trading behavior and observed that they sometimes trade too frequently to their disadvantage. Loss aversion, representativeness, availability and anchoring biases were great contributors to market inefficiencies as per a study done in Tunisia (Chaffai \& Medhioub, 2014). Many studies show a negative impact of behaviour biases on investments. Kafayat, (2014) and Chen et al., (2007) however show a positive effect of biases on investment decisions as evidenced by superior returns. Arthur (2014) finds that although some behavioural biases affect investors, other behaviours like loss aversion have no effect. Methodology inconsistencies have also been observed. A study by Arthur (2014) on investor biases at NSE used a sample of 30 respondents selected conveniently. Similarly Kimeu et al., (2016) did a similar study with a sample of 80 respondents. While these numbers represent the population, there is a need to consider a larger sample for this kind of study.

With more information spreading fast in the current world, decision making has even grown more complex due to the many options available to investors. Individual investors still experience challenges in investment selection and decision making due to limited financial experience (Winchester et al., 2011). Empirical evidence is in favour of the fact that behavioural biases affect investment decisions. However, it is not clear the extent to which these biases affect individual investors as some have positive impact while others impact decisions negatively. There also lacks consensus on which biases affect investors the most. With markets continuing to grow, what behavioural biases affect investment decisions for individual investors at NSE?

\subsection{Research Objective}

To determine the effect of behavioural biases on investment decisions for individual investors at Nairobi Securities Exchange.

\subsection{Value of the Study}

This study will contribute to knowledge in the field of behaviour finance, which can be used for reference by other scholars who want to advance their knowledge in this field. The knowledge will be of great use to those with interest in the field. At the end of the study, limitations and future areas of research that one can focus on will be outlined and this could form a reference point for future researchers in the area.

The results obtained will enable individual investors to be cognizant of the behaviour aspects they pose which can affect their decision making and thus do careful analysis prior to undertaking their investments. The study will look into enlightening individual investors on factors they should be cautious of when selecting their investments and shed light on individual behaviours that affect performance. 
Investment advisors and brokers will be better able to identify emotional and cognitive aspects of individual investor's behaviour and better advise the investors on how to evaluate investments without being negatively influenced by their behaviour. The regulators of financial markets will use results obtained to develop appropriate trainings and investor awareness programs.

\section{CHAPTER TWO}

\section{LITERATURE REVIEW}

\subsection{Introduction}

This chapter will look at what other researchers have done in relation to behavioural biases and how those biases affect investment decisions. It involves a review of the theories and empirical evidence around this field.

\subsection{Theoretical Review}

This part will focus on theories that this study bases on and the relevance of such theories to the particular topic. The researcher mainly considered prospect theory, expected utility theory, heuristics theory, efficient markets and regret theories.

\subsubsection{Prospect Theory}

Kahneman and Tversky(1979) who developed the theory looked at how people make choices among risky alternatives with uncertain probabilities. According to this theory people make choices based on likely gains and losses without necessarily focusing on the outcome. Human beings give more preference to probable gains than to probable loss even when the result might be the same. Several biases that contribute to this behavior include framing, fearing losses and regrets.

Framing refers to the set of words that are used to describe phenomena. When investors are making decisions, they prefer the option that is stated in terms of probable gains to the ones stated in probable losses. Peoples' psychology guides how decision problems are perceived and outcomes evaluated is guided by how the problem is framed. Loss aversion arises from the notion that people prefer avoiding losses double the times they prefer gains. How an investor avoids losses depends on prior investment performance. Regret aversion bias comes up as investors make efforts to avoid emotional pain brought about by regretting decisions made.

This theory is relevant since individuals who are afraid of losing, end up foregoing some attractive investment opportunity for fear of loss and thus making irrational investment 


\section{International Journal of Social Science and Economic Research}

ISSN: $2455-8834$

Volume: 05, Issue: 05 "May 2020"

decisions. Unlike normative models that focus on optimal decisions, prospect theory tries to model real life situations.

\subsubsection{Regret Theory}

This theory holds that there are key factors that affect the process of deciding among alternatives which have been ignored by conventional theories (Loomes \& Sugden, 1982). Such factors include the capability of an individual to look forward to experience joy or regret based on their actions. The theory rests on the belief that people experience sensations, for instance regret or rejoicing and that they anticipate and consider these sensations in decision-making.

Regret theory is observable at individual level as they focus not only on what they will achieve but also on the results they would get by selecting a different path (Diecidue \& Somasundaram, 2017). This theory contributes to the conceptual framework, as its implications are that when investors are choosing between risky alternatives, they might end up not selecting the best course of action, since they are afraid of regretting the choice they make.

\subsubsection{Expected Utility Theory}

This theory states when investors do chose among risky alternatives they compute their total expected utility by multiplying weighted values of the outcomes with the respective probabilities. Bernoulli (1738) who pioneered the utility theory looked at how the price of a gamble is determined. There are two different types of utility; subjective expected utility which concerns uncertain choices and Von Neumann-Morgenstern theory for risky choices (Mongin, 1997). Subjective probability is derived from people's preference over actions (Schmeidler, 1984).

Tversky and Kahneman (1974) criticized the expected utility from both descriptive and normative views arguing that it does not adequately describe an individual's choice among risky options. This theory lays a foundation for this study by advocating for rationality among investors. As modern research posits that investors experience irrationality arising from behavior aspects of individuals, the researcher will examine if such biases exist and how they influence investment decision making.

\subsubsection{Heuristics theory}

When faced with tough decisions under uncertainty, investors develop quick models of analyzing the problem and making decisions. Tversky and Kahneman (1974) established that people decide based on their beliefs regarding the likelihood of the events. These confidences when expressed in numbers or in subjective probabilities make reduce the complexities of assessing many probabilities when making choices. They identified three heuristic that guide decision-making. 


\section{International Journal of Social Science and Economic Research}

ISSN: $2455-8834$

Volume: 05, Issue: 05 "May 2020"

The three types of heuristics are; anchoring, availability and representativeness. Anchoring refers to a situation where investors refer to some initial piece of information they have before making choices. Availability bias is when decisions are made based on recent events that people can remember and representativeness is when one relies on past occurrences when making decisions.

\subsubsection{Efficient Markets Theory}

The efficiency of a market refers to the extent to which the prices show all the available information. Fama, the founder of this theory was of the opinion that investors are not in a position to out shine the market since any available information will be accounted for in the prices (Fama, 1970). He developed three forms of market efficiency; A strong form in which prices will show every current and future information, semi strong form where prices show past and current information and weak form where past information is incorporated. This theory contributes to this study because the decision investors make are influenced by the information they have. Shiller (2003) is of the opinion that behaviour finance triggers people to find more information about financial markets.

\subsection{Determinants of Investment Decisions}

How one behaves is a result of several factors and people have different motives when making decisions. Psychology and emotions are major players when selecting a course of action.

\subsubsection{Behavioural Biases}

These are behaviour factors which influence peoples thinking and lead to irrationality. Some behavioural biases are; overconfidence, herding, disposition effect, narrow framing, cognitive dissonance, mental accounting and heuristics. Overconfidence is the act of overestimating one's capabilities. Odean (1998) established that overconfidence causes trading volumes to increase and some traders to ignore good information brought in by rational investors. Herding is the likelihood of investors to imitate the investment behaviour of other friends and relatives blindly. The effect of this behaviour fueled the 2008 financial crisis as people followed their peers thus leading to huge losses.

Disposition behaviour is the likelihood of individual investors to classify investments as either winners or losers. As a result, they may end up holding onto poor performing investments or sell off bullish investments due to past performance. Investors with this behaviour are likely to sell off investments which have increased in value while keeping the ones that have dropped value (Henderson, 2012). Shefrin and Statman (1985) opined that people continue investing in low performing ventures with the hope that the situation will improve with time. 


\section{International Journal of Social Science and Economic Research}

ISSN: $2455-8834$

Volume: 05, Issue: 05 "May 2020"

Availability bias is evident when people assess the number of times an event has occurred and they consider instances that linger in their mind (Tversky \& Kahneman, 1974). Investors are likely to overestimate the likelihood of certain events based on recent occurrences. Anchoring refers to the tendency rely heavily on an initial point of reference to make subsequent decisions. When people make choices they do so based on some initial starting point which is then adjusted to give final results (Tversky \& Kahneman, 1974). Representativeness is the tendency to make decisions based on how a situation looks like and not on critical evaluation of the problem. There is a probability to make decisions based on past occurrences, known as stereotyping, without careful analysis of the current situation.

\subsubsection{Demographics}

Demographics and some social economic aspects of individuals affect their decision making. Demography involves looking at various characteristics of a population. This includes; age, gender, occupation, income level, investment knowledge, and the level of education of the investors. Female investors, experienced, old people and investors with low education levels have a tendency to invest in high risk investments (Onsomu, Kaijage, Aduda, \& Iraya, 2017a).Experienced investors have confidence in their decisions and are likely to select options that give them good returns. The appetite for high risk investments by lowly educated people may be attributable to inadequacy of information available to them.

Demographic characteristics greatly influence the behaviour of investors and how their portfolios perform (Nyamute, 2016). These demographic characteristics affect an individual's satisfaction with their decisions. Demographic factors like age, occupation, education level and income amount of investors has been seen to influence investors buy, sell or hold decisions and will influence how they respond to various events (Nyamute, 2016). These characteristics influence the amount of risk an investor is willing to take which subsequently influences their returns.

\subsubsection{Personal Traits}

The characteristics that an investor possess and are specific to an individual for instance in terms of their risk tolerance influences their decisions. Risk seeking investors will choose risky options in expectation for high returns. Those that fear risk will make conservative choices. Investor experience will also affect decision making. An experienced investor will make more informed decisions as they understand the trends in the markets.

Rzeszutek (2015) however found that people who have some traits such as eagerness to explore new ventures, have high self-confidence and are ready to undertake risky ventures will less likely to be affected by behavioural biases. Sadi et al (2011) found that people's perceptions bring errors in their decision making. Extroversion, openness, randomness and commitments are some 


\section{International Journal of Social Science and Economic Research}

ISSN: $2455-8834$

Volume: 05, Issue: 05 "May 2020"

traits that affect individuals. Individuals can be categorized into different groups based on the characteristics they possess and this influences their investments.

\subsection{Empirical Studies}

Toma (2015) did a study on behavioral biases for investors at Bucharest Stock Exchange. In the study they focused on three biases most exhibited by investors namely; over confidence, disposition and representativeness biases. The accounts for 21 individual investors were targeted for the study and investor characteristics used to test for the behavioural biases above. They found that investors exhibited all the three biases. They however recommended a future study with more variables and an extended period.

A study by Hayat and Anwar (2016) looked at how behavioural biases affect investments in Pakistan while moderating for the role of financial literacy. Simple survey questionnaires were used and data collected for 158 individuals investing at the Stock Exchange in Pakistan. Disposition effect, overconfidence and herding were found to significantly and positively affect investor decisions. There was more overconfidence bias for active traders while more passive traders demonstrated herding behaviors. The study advocates for training of investors and investment in research to increase investor awareness and guide them in undertaking technical analysis before investing.

Bashir, AaqibaJaved, et al., (2013) aimed to establish the factors affecting individual investor's behaviour in Pakistan. One hundred and twenty five investors were sampled and data collected from them through questionnaires. They identified dividends, firm's reputation, people's feelings on a firm's products, building wealth and community engagement as the top variables that influence an investor's behaviour. Issues to do with the markets such as opinions of firm's stock brokers and movements in prices were marked as least important and this is attributable to the fact that Pakistan lacks an organized market hence people are not aware of some of these issues.

Adel and Mariem (2013) looked at how investors are affected by overconfidence by studying 27 companies trading at Tunis between 2002 and 2010.They sought to specifically establish how overconfidence, trading volume and volatility affect decisions on investments. Results indicate that overconfidence bias influences decision making.

Mahina, Muturi, and Florence (2017) aimed to test how behavioral biases influence investments done by investors in Rwanda Stock Exchange. In the study, they focused on self-serving bias, self-attribution bias, loss aversion, over optimism bias and confirmatory bias. Their study was founded on herding, heuristic and prospect theories. They studied a sample of 374 respondents and concluded that most investors suffer from behavioural biases and should thus seek the advice of investment analysts or fund managers on the performance of securities they are interested in. 
International Journal of Social Science and Economic Research

ISSN: 2455-8834

Volume: 05, Issue: 05 "May 2020"

Kimeu et al., (2016) sought to identify behaviours that affect individual investor's decisions at NSE. A sample of 80 respondents was selected from whom data was collected using questionnaires. Results indicate that prospect, heuristics and herding positively impacted investments. They advocated for investors to form investment groups as a majority of individual decisions was seen to be influenced by other investors' choices.

Onsomu et al., (2017) looked at how demographics affect behavioural biases at the NSE. They carried out a cross sectional analysis for the year 2015 among 279 individual investors. The findings showed that representatives bias, availability and anchoring biases affected investors. There was no effect of age, education and experience. Men were shown to suffer more from biases as opposed to females.

\subsection{Summary of Literature Review and Research Gap}

Many finance and economic theories have always assumed that investors consider all available information and act rationally. According to Bernstein (1996) investors have been observed to show incompetence, inconsistency and irrational behaviour when making decisions under risk.

Some studies have found that institutional investors are able to do technical analysis and thus make more informed decisions as compared to individual investors who rely on noise and follow other investors. The literature has reviewed the behaviours that potentially affect investors and discussed some as; overconfidence, representativeness, availability bias, loss aversion and regret. The literature also reviewed the role of other control factors; age, gender, financial knowhow and the trading experience of investors in making decisions. Empirical evidence is in favour of the fact that behavioural biases affect investment decisions. However, it is not clear the extent to which these biases affect individual investors and which biases affect investors the most. In this study, this is the gap the researcher aims to fill.

\subsection{Conceptual Framework}

This provides a diagram depicting the relation between the variables under observation. 
Independent Variables

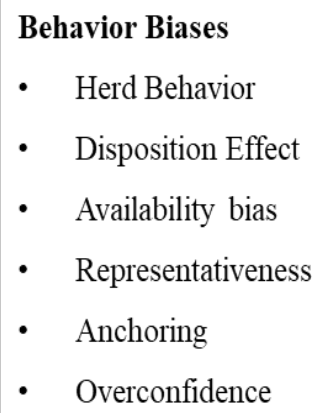

Figure 2.1: Conceptual Framework (Researcher, 2019)

\section{CHAPTER THREE}

\section{RESEARCH METHODOLOGY}

\subsection{Introduction}

The chapter outlines the methodology used by the researcher. It highlights the design used for this research, the population studied, sample size, sampling method used, techniques used for collecting data and a description of how data were analysed.

\subsection{Research Design}

Kombo and Tromp (2006) define research design as how a particular research is structured. Descriptive research design was used for this study. Gravetter and Forzano (2011) describe this design as one that entails measurement of a given set of variables that exist naturally. Descriptive research attempts to describe status of the subject under investigation and describes phenomena as it is. It is a useful design in describing things such as human behaviour, attitudes, values and characteristics. This study focused on the quantitative aspects on investments as influenced by behaviour.

\subsection{Population}


Mugenda and Mugenda (2003) define population as a group that inhibits observable characteristics, which are of interest to the researcher. Saunders et al., (2009) define a population as an entire set of elements about which some conclusions can be drawn in a study. The researcher looked at the population for this study as all individual investors at NSE in Kenya. Approximately, there were 1,192,331 individual investors at NSE as per the CMA Quarterly Statistical Bulleting Q1, 2019(CMA, 2019) who formed the population for this study.

\subsection{Sampling Technique and Sample Size}

A sampling plan describes how the sample is selected, the sampling frame, sampling unit, and the size that is selected. A sampling frame outlines all elements of a population from which a sample is chosen (Cooper \& Schindler, 2003).A sample of 100 investors was settled for in this study by using a formula by Kombo and Tromp (2009) which uses a covariance of 0.3 as below.

$\mathrm{n}=\frac{N C^{2}}{C^{2}+(N-1) e^{2}}$

Where:

$\mathrm{n}=$ the sample size

$\mathrm{N}=$ Population Size

$\mathrm{C}=$ Covariance of the variables assumed at 0.3

e is the error term assumed at 0.03 for the study.

$\mathrm{n}=\frac{1192331 * 0.3^{2}}{0.3^{2}+(1192331-1) 0.03^{2}} \quad=100$ respondents

$\mathrm{n}=100$

The questionnaires were administered to the respondents through their brokers at NSE by visiting their offices between $5^{\text {th }}$ and $18^{\text {th }}$ October 2019. The brokers assisted in having the questionnaires filled in by investors visiting their offices for trading.

\subsection{Data Collection}

The researcher collected primary data through questionnaires, which are very useful in collecting information that is not directly observable. For example; people's feelings, attitude, values and their experiences. The researcher collected the data from convenient but random sampling of investors visiting their stockbroker offices. The questions asked included open and closed ones to avoid any limitations on information disclosure. The first part of the questions was on general information regarding the control variables then the questions to address whether investors have 
behavioural biases and finally some questions on investor's returns since returns were used as the measure of how the biases affect investment decisions.

\subsection{Data Analysis}

The collected data were cleaned up and analysed using STATA 13.0. The researcher computed percentages and means by groups and plotted where necessary. The percentage gain was calculated as (Outcome - invested amount/invested amount) *100). The researcher used Shapiro -Wilk to test for normality, Breusch-Pagan/Cook-Weisberg test to test for heteroscedasticity and Variance Inflation Factors (VIF) to test for multicollinearity. Since the percentage return was not normally distributed (Shapiro $\mathrm{W}$ test $\mathrm{P}<0.05$, and some percentage returns were negative, the researcher added the (minimum value $+5=105$ ) then log-transformed. This addition was necessary because logarithm of a negative number is undefined. The multivariable model included all behavioural biases with additional adjustments for age, sex, and education. The researcher aimed to establish a regression model as below;

$\mathrm{Y}=\alpha+\beta 1 \mathrm{X}_{1}+\beta 2 \mathrm{X}_{2}+\beta 3 \mathrm{X}_{3}+\beta 4 \mathrm{X}_{4}+\beta 5 \mathrm{X}_{5}+\beta 6 \mathrm{X}_{6}+\beta 7 \mathrm{X}_{7}+\beta 8 \mathrm{X}_{8}+\beta 9 \mathrm{X}_{9}+\varepsilon$

The variables were explained as below;

Y - The outcome dependent on investor's behaviour (Percentage return)

The other variables were;

$\mathrm{X}_{1}$ - Overconfidence

$\mathrm{X}_{2}-$ Herd Behaviour

$\mathrm{X}_{3}-$ Disposition Effect

$\mathrm{X}_{4}-$ Representativeness Bias

$\mathrm{X}_{5}-$ Availability Bias

$\mathrm{X}_{6}-$ Anchoring

$\mathrm{X}_{7}-$ Age

$\mathrm{X}_{8}-$ Gender

$\mathrm{X}_{9}-$ Level of Education 


\subsection{Operationalization of the variables}

Table 3.1: Operationalization of the variables

\begin{tabular}{|c|c|c|c|}
\hline Variable & Definition & Indicator & Measurement \\
\hline $\begin{array}{l}\text { Investment } \\
\text { decision making }\end{array}$ & $\begin{array}{l}\text { Selecting one option } \\
\text { among many available } \\
\text { alternatives }\end{array}$ & $\begin{array}{l}\text { - The returns that } \\
\text { investors earn } \\
\text { - The securities that } \\
\text { investors select }\end{array}$ & Ratio Scale \\
\hline $\begin{array}{l}\text { Overconfidence } \\
\text { bias }\end{array}$ & $\begin{array}{l}\text { This bias describes a } \\
\text { situation in which one } \\
\text { over estimates their } \\
\text { ability }\end{array}$ & $\begin{array}{l}\text { - } \text { Over trading } \\
\text { - } \text { Holding stocks }\end{array}$ & Nominal Scale \\
\hline Herd Behaviour & $\begin{array}{l}\text { Refers to investing in } \\
\text { stocks that others are } \\
\text { investing in. }\end{array}$ & $\begin{array}{l}\text { - Oversubscription of } \\
\text { shares } \\
\text { - Mass selling of } \\
\text { shares }\end{array}$ & Nominal Scale \\
\hline Disposition bias & $\begin{array}{l}\text { The tendency of } \\
\text { investors to fear losing } \\
\text { that they sell stocks } \\
\text { that have started to gain } \\
\text { while holding on } \\
\text { losers. }\end{array}$ & $\begin{array}{l}\text { - Short investment } \\
\text { periods }\end{array}$ & Nominal Scale \\
\hline Heuristics & $\begin{array}{l}\text { They are a form of } \\
\text { problem-solving } \\
\text { method in which } \\
\text { people try to use } \\
\text { shorter routes. }\end{array}$ & $\begin{array}{ll}\text { - } & \text { Anchoring } \\
\text { - } & \text { Availability bias } \\
\text { - } & \text { Representativeness }\end{array}$ & Nominal Scale \\
\hline
\end{tabular}

Source: Researcher, 2019 


\section{CHAPTER FOUR}

\section{DATA ANALYSIS, FINDINGS AND DISCUSSIONS}

\subsection{Introduction}

This section outlines general information with regard to the respondents of the questionnaires administered. Both descriptive and inferential statistics were used in analysing data and results obtained were expressed in percentages and frequencies and presented in tables and figures. This chapter also presents results of regression analysis.

\subsection{Rate of response}

Out of 100 questionnaires that were issued, 84 of them were completed and returned. This represents $84 \%$ response rate and according to Mugenda and Mugenda (2008), a rate of response that exceeds $70 \%$ is excellent for any study.

Table 4.1: Response Rate

\begin{tabular}{|l|l|}
\hline Total Questionnaires administered & 100 \\
\hline Completed and returned & 84 \\
\hline Response rate & $\mathbf{8 4 \%}$ \\
\hline
\end{tabular}

Source: Researcher, 2019

\subsection{Descriptive analysis of study variables}

This section gives a presentation of the results obtained for each of the variables. The results were put in percentages and frequencies and presented through tables and figures.

\subsubsection{Respondents Gender}

The aim of looking at gender was to find out if investor's gender had an influence on investment decisions. Of the 100 investors at NSE interviewed, 45 of them were male, representing a $53.57 \%$ as shown in the below that follows. 
International Journal of Social Science and Economic Research

ISSN: 2455-8834

Volume: 05, Issue: 05 "May 2020"

Table 4.2: Gender of the respondents

\begin{tabular}{|c|c|c|}
\hline Gender & Frequency & Percentage \\
\hline Male & 45 & 53.57 \\
\hline Female & 39 & 46.43 \\
\hline Total & $\mathbf{8 4}$ & $\mathbf{1 0 0}$ \\
\hline
\end{tabular}

Source: Researcher, 2019

The results indicate a higher number of male investors at NSE.

\subsubsection{Respondents Age}

A question was asked on respondents' age to find out if age was a determinant when making decisions. Majority of the investors were young as indicated on the table below.

Table 4.3: Age of respondents

\begin{tabular}{|c|c|c|}
\hline Age & Frequency & Percentage \\
\hline 25 years and below & 24 & 28.57 \\
\hline Between 26-35 years & 47 & 55.95 \\
\hline Between 36- 45 years & 11 & 13.1 \\
\hline Between 46- 60 years & 2 & 2.38 \\
\hline Over 60 years & 0 & 0 \\
\hline Total & $\mathbf{8 4}$ & $\mathbf{1 0 0}$ \\
\hline
\end{tabular}

Source: Researcher, 2019

Majority (55.95\%) of the investors were aged 26-35 years of age and only 2.38\% were aged 46 years and above.

\subsubsection{Education level of the respondents}

A question on the level of education was asked to test whether an investor's education influences their investment decisions. Table 4.3 below outlines the characteristics of the investors in terms of their education. 
International Journal of Social Science and Economic Research

ISSN: $2455-8834$

Volume: 05, Issue: 05 "May 2020"

Table 4.4: Education of Respondents

\begin{tabular}{|c|c|c|}
\hline Education & Frequency & Percentage \\
\hline Primary school & 0 & 0 \\
\hline Secondary school & 1 & 1.19 \\
\hline Certificate/diploma & 2 & 2.38 \\
\hline Bachelor's Degree & 58 & 69.05 \\
\hline Master's Degree & 23 & 27.38 \\
\hline Doctorate Degree & 0 & 0 \\
\hline Total & $\mathbf{8 4}$ & $\mathbf{1 0 0}$ \\
\hline
\end{tabular}

Source: Researcher, 2019

Results indicate that almost all $(81 / 84,96.43 \%)$ of the investors had at least a Bachelor's Degree. Out of these, $27 \%$ had a Master's Degree.

\subsubsection{Other Characteristics of the investors}

\subsubsection{Sale of investments}

Most investors 34, (40.96\%) sell their shares when prices start going up, 27 (32.53\%) sell after expiry of a satisfactory period, $11(13.25 \%)$ when prices start going down, 3 (3.61\%) when others start selling while $8(9.64 \%)$ sell for other reasons such as upon attainment of a desires return level. Results are as presented in the figure below.

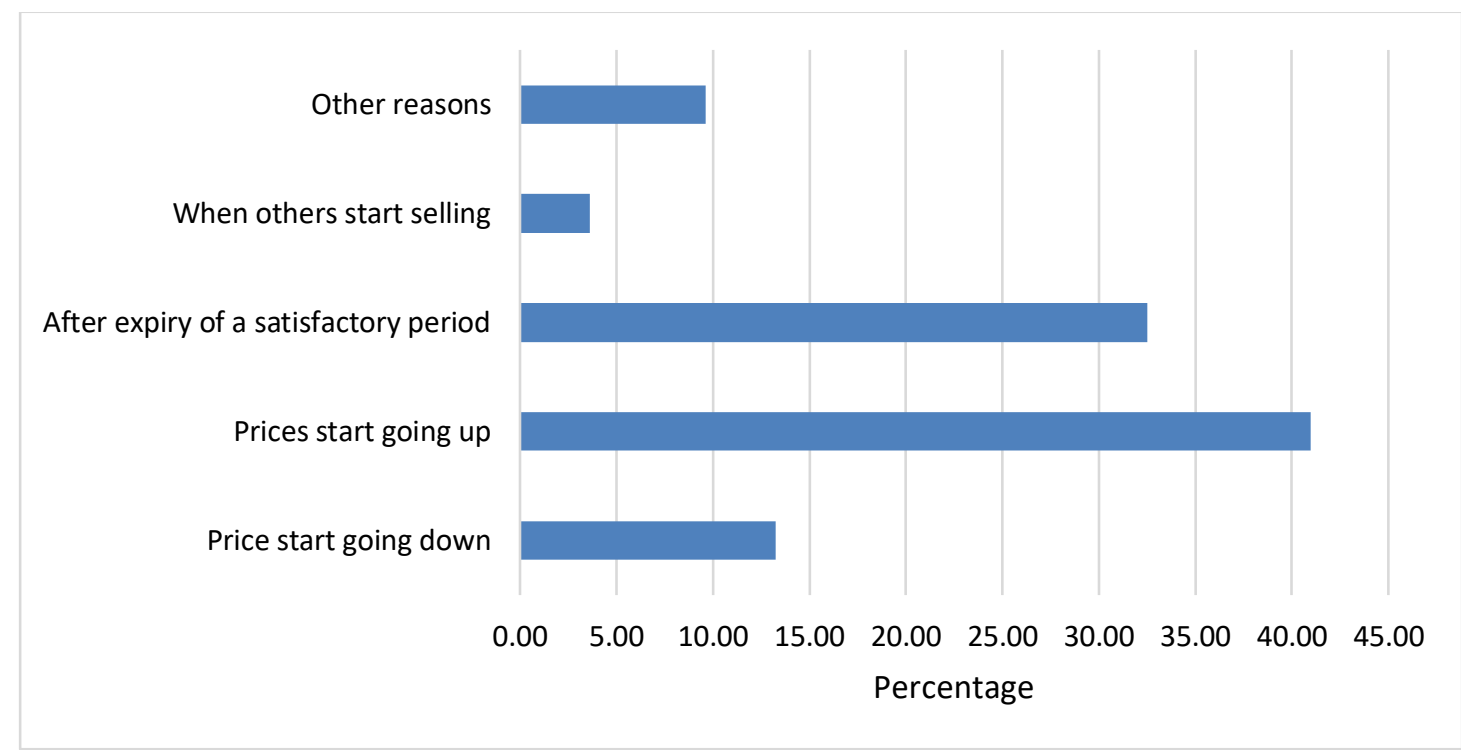

Figure 4.1: Sale of Investments (Researcher, 2019) 
When the prices of shares go down, majority $(33,40.24 \%)$ prefer buying more of the shares and holding, $(27,32.93 \%)$ wait for prices to stabilize then sell them off, $(8,9.76 \%)$ sell off the shares, while $(13,15.85 \%)$ do other things such as doing more analysis into why the share went down so as to determine the course of action.

\subsubsection{Investment Consideration}

When building an investment portfolio, most investors reported considering other investment options that they have ventured in previously $(35,41.67 \%)$ or tend to seek expert advice (34, $40.48 \%)$. Only $(6,7.14 \%)$ focus only on the stocks that they have previously invested in, (4, $4.76 \%$ ) consider other factors such as careful analysis of the market and $(4,4.76 \%)$ seek recommendations from friends.

\section{Table 4.5: Investment Consideration}

\begin{tabular}{|l|l|l|}
\hline Investment Consideration & Frequency & Percentage \\
\hline Focus on stocks previously invested & 6 & 7.14 \\
\hline Focus on investment options not ventured in & 35 & 41.67 \\
\hline Recommendations from friends & 4 & 4.76 \\
\hline Experts advice & 34 & 40.48 \\
\hline Other factors & 4 & 4.76 \\
\hline Total & $\mathbf{8 3}$ & $\mathbf{1 0 0}$ \\
\hline
\end{tabular}

Source: Researcher, 2019

\subsubsection{Investment Horizon}

Most investors $(32,39.02 \%)$ at NSE hold shares for over two years, 27 (32.93\%) for one month to one year, $(18,21.95 \%)$ for between one and two years, and $(4,4.88 \%)$ for one month. 


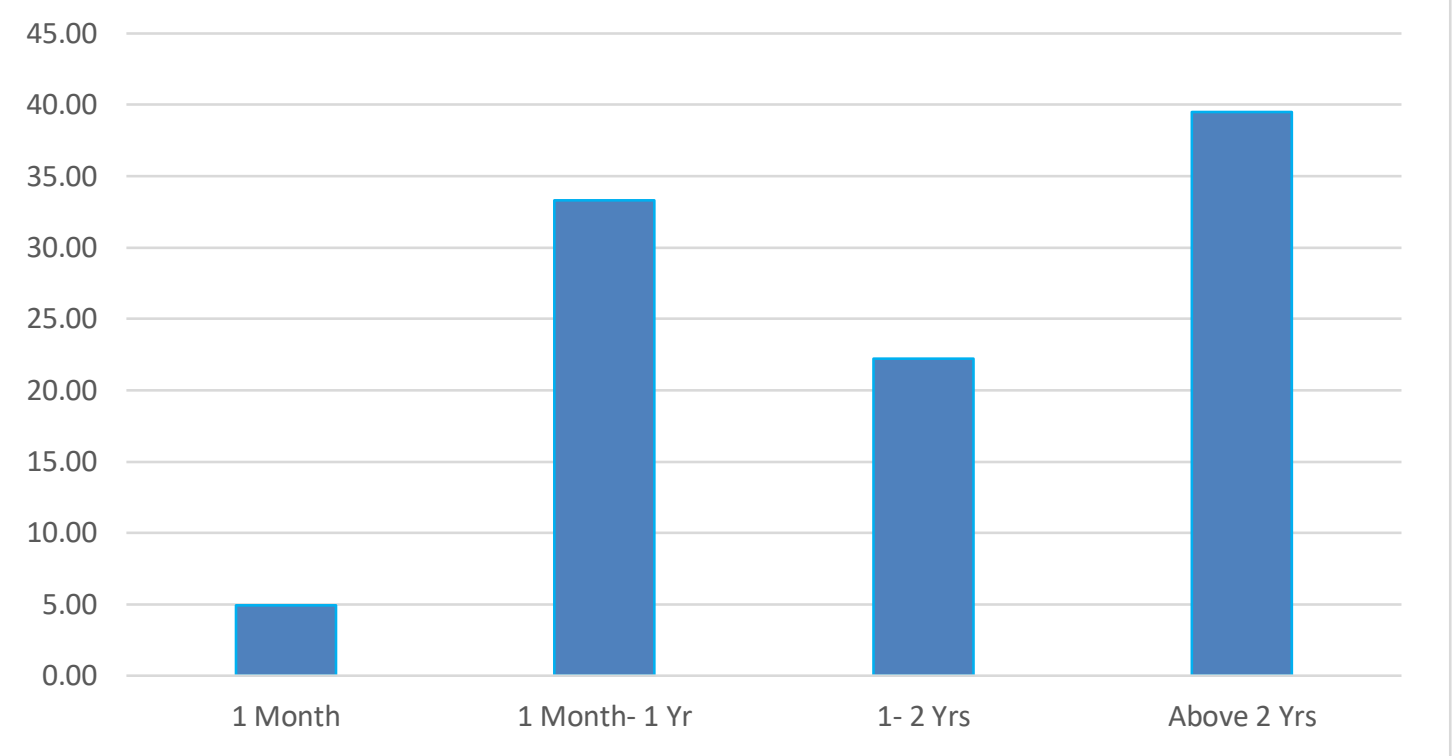

Figure 4.2: Investment Horizon (Researcher, 2019)

\subsubsection{Amount of investment}

The question on amount of money invested was asked to assist in establishing how behavioural biases affect investment decisions as measured by the investor's returns. The results are as indicated in the figure below.

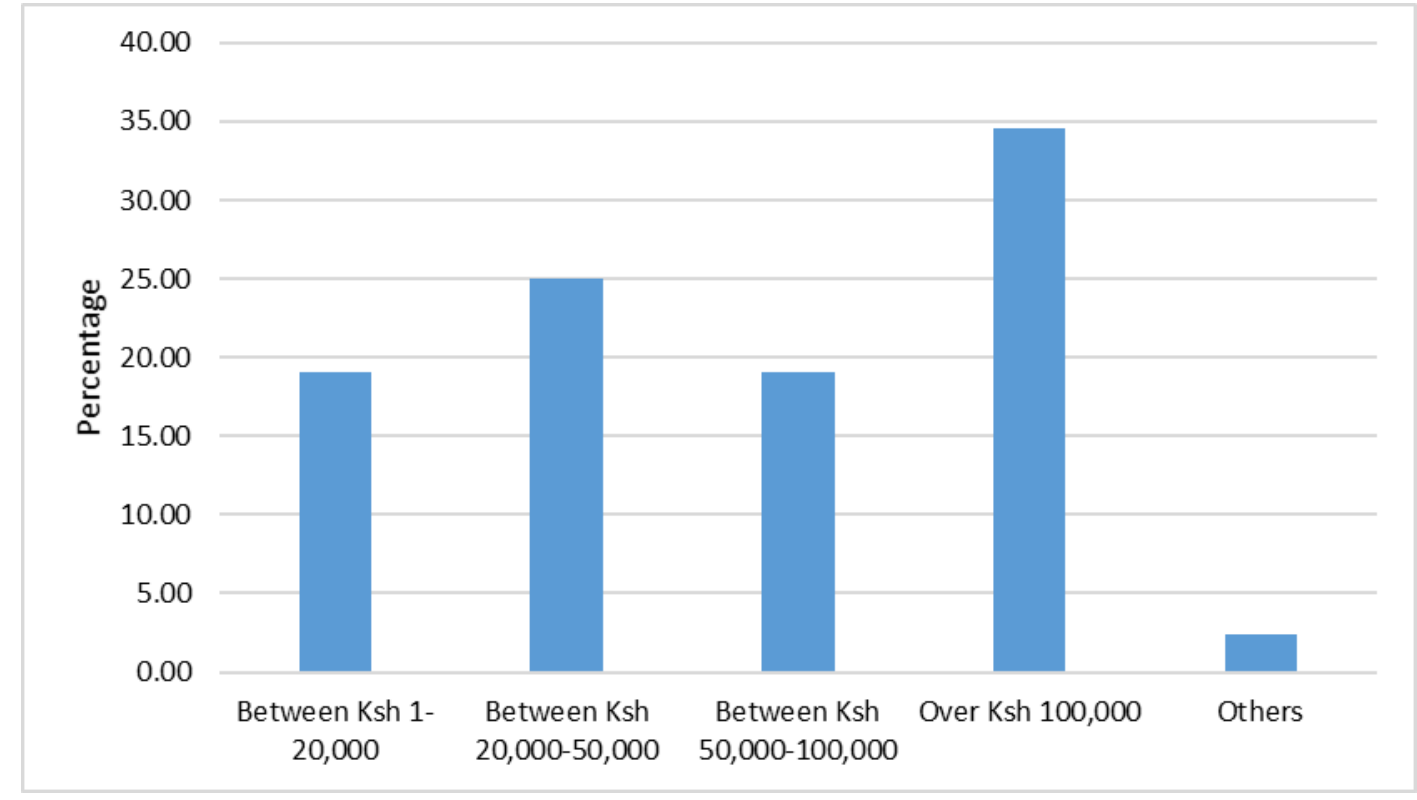

Figure 4.3: Amount of Investment (Researcher, 2019) 
Investment in stocks was highest (34.52\%) in the category of those investing over Ksh 100,000 while similar proportions (19\%)were invested in the Ksh 1-20,000 and 50,000-100,000. Investments of 20,000-50,000 were at the middle with $25 \%$.

\subsubsection{Overconfidence}

In terms of investment confidence, majority $(42,51.22 \%)$ would prefer to live with the outcome of whatever they chose, $(30,36.59 \%)$ were confident about their decision and $(10,12.20 \%)$ were afraid of making a bad decision. Results are shown below.

Table 4.6: Overconfidence

\begin{tabular}{|l|l|l|}
\hline Overconfidence & Frequency & Percentage \\
\hline Afraid of decisions & 10 & 12.20 \\
\hline Confident in their decisions & 30 & 36.59 \\
\hline Neutral & 42 & 51.22 \\
\hline Total & $\mathbf{8 2}$ & $\mathbf{1 0 0 . 0 0}$ \\
\hline
\end{tabular}

Source: Researcher, 2019

When looking at the motivating factor among those who make their investment decisions, $41.67 \%$ are confident in their investment decisions, $37.50 \%$ do it in order to control their money, $12.50 \%$ enjoy doing it, while $6.94 \%$ do it for other reasons such as their vast experience in stocks.

\subsubsection{Representativeness}

After identifying a share that performed really well in the past, almost all investors at NSE (80, $96.39 \%$ ) conduct some analyses to establish whether the good performance is likely to continue while the rest rush to buy the share.

Table 4.7: Representativeness

\begin{tabular}{|l|l|l|}
\hline Representativeness & Frequency & Percentage \\
\hline Rush to buy & 3 & 3.61 \\
\hline Careful analysis & 80 & 96.39 \\
\hline Total & $\mathbf{8 3}$ & $\mathbf{1 0 0 . 0 0}$ \\
\hline
\end{tabular}

Source: Researcher, 2019

When asked about relying on experience, most investors $(53,63.10 \%)$ reported that careful analysis of market information guides what they chose to invest in. Only 19 (22.62\%) chose to invest based on experience on performance of certain stocks. 


\subsubsection{Anchoring}

This question was asked to establish whether investors are affected by a piece of information, they might have previously come across.

Table 4.8: Anchoring

\begin{tabular}{|l|l|l|}
\hline Anchoring & Frequency & Percentage \\
\hline Agree & 67 & 79.76 \\
\hline Does not matter & 10 & 11.90 \\
\hline Disagree & 7 & 8.33 \\
\hline Total & $\mathbf{8 4}$ & $\mathbf{1 0 0}$ \\
\hline
\end{tabular}

Source: Researcher, 2019

Most investors (67/84) representing a $79.76 \%$ agreed that they refer to an initial piece of information that they might have received about a certain stock investment option. Interestingly, $(7,8.33 \%)$ disagreed to referring to an initial information while $(10,11.90 \%)$ reported that the initial information does not matter.

\subsubsection{Herding Behaviour}

This was to test whether investors follow the decisions of other investors, friends and relatives. Results are as shown below.

\section{Table 4.9: Herding}

\begin{tabular}{|l|l|l|}
\hline Herding & Frequency & Percentage \\
\hline Agree & 15 & 18.07 \\
\hline Does not Matter & 36 & 43.37 \\
\hline Disagree & 32 & 38.55 \\
\hline Total & $\mathbf{8 3}$ & $\mathbf{1 0 0}$ \\
\hline
\end{tabular}

Source: Researcher, 2019

Only $15(18.07 \%)$ of the investors agreed that they consider what friends are buying when purchasing their stocks, for $(36,43.37 \%)$ it does not matter what their friends are buying and (32, $38.55 \%$ ) make decisions independent of others.

\subsubsection{Disposition Effect}

A question was asked to test how afraid people are of making losses. When asked whether they prefer making investments stated in terms of gains or losses, $(69,85.19 \%)$ of the investors would 
prefer Ksh 1000 with a 50\% chance of gaining compared to $(12,14.81 \%)$ who would prefer Ksh 1000 with a $50 \%$ chance of losing though the net effect is the same.

Table 4.10: Disposition Effect

\begin{tabular}{|l|l|l|}
\hline Gain/loss & Frequency & Percentage \\
\hline Gain & 69 & 85.19 \\
\hline Loss & 12 & 14.81 \\
\hline Total & $\mathbf{8 1}$ & $\mathbf{1 0 0}$ \\
\hline
\end{tabular}

Source: Researcher, 2019

The researcher considered a situation where a share goes down and one loses, majority (56, $66.67 \%$ ) would watch from a distance how the share behaves without rushing to invest in it. Fifteen $(17.86 \%)$ would try again next time hoping for better results and two $(2.38 \%)$ would never invest again in that share.

\subsubsection{Availability bias}

When investing in stocks, 59 (71.08\%) carry out adequate research to establish the best stocks to invest in, $14(16.87 \%)$ choose stocks that are readily available and those that they know well about, while $10(12.05 \%)$ refer to past occurrences to determine when to invest.

Table 4.11: Availability bias

\begin{tabular}{|l|l|l|}
\hline Availability & Frequency & Percentage \\
\hline Refer to past performance & 10 & 12.05 \\
\hline Research for best option & 59 & 71.08 \\
\hline Buy familiar stocks & 14 & 16.87 \\
\hline Total & $\mathbf{8 3}$ & $\mathbf{1 0 0}$ \\
\hline
\end{tabular}

Source: Researcher, 2019

\subsubsection{Return on investment}

The researcher asked a question on the percentage return that investors had achieved from their investment. This was to enable the researcher compare how the returns for investor experiencing behavioural biases differed from those without biases. Out of the 100 investors interviewed 48 disclosed information on their returns. Forty investors presenting a $83.33 \%$ had a positive percentage return with $(8,16.67 \%)$ having a negative gain. The mean return was $29.28 \%$.

\subsubsection{Behavioural biases}

Below table represents a summary of the means for the behavioural biases. 
International Journal of Social Science and Economic Research

ISSN: 2455-8834

Volume: 05, Issue: 05 "May 2020"

Table 4.12: Summary of the Means

\begin{tabular}{|c|c|c|c|c|c|c|}
\hline 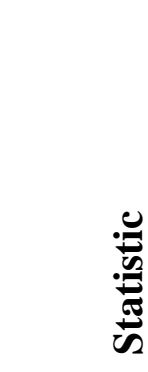 & 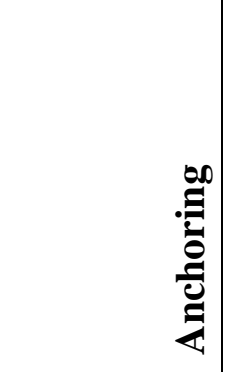 & لِّ & 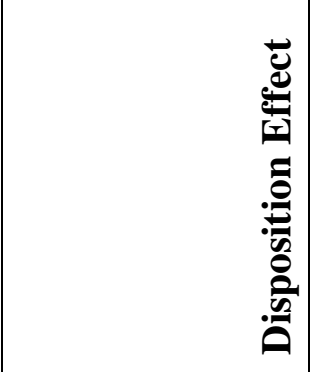 & 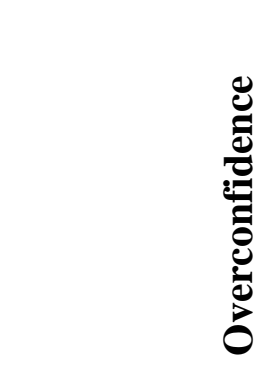 & 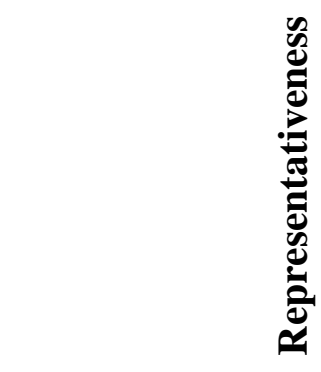 & 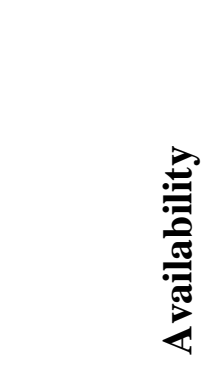 \\
\hline Mean & 1.286 & 2.205 & 2.905 & 2.39 & 1.964 & 1.952 \\
\hline $\mathbf{N}$ & 84 & 83 & 84 & 82 & 83 & 83 \\
\hline
\end{tabular}

Source: Researcher, 2019

\subsection{Regression Diagnostic Tests}

To derive the relationship between the variables, the researcher used simple regression analysis. Some tests as below were done to ensure that the model satisfies the assumptions of linear regression.

\subsubsection{Normality}

Normality was tested for using Shapiro Wilk test. Since the percentage gain was not normally distributed (Shapiro W test $\mathrm{P}<0.05$, and some percentage gains were negative, the researcher added the (minimum value $+5=105$ ) then log-transformed.

Table 4.13: Normality Test

\begin{tabular}{|l|l|l|}
\hline & Shapiro- Wilk & \\
\hline & $\mathrm{df}$ & P value \\
\hline Anchoring & 84 & 0.08 \\
\hline Herding & 83 & 0.94 \\
\hline Disposition & 84 & 0.05 \\
\hline Overconfidence & 82 & 0.06 \\
\hline Representativeness & 83 & 0.14 \\
\hline Availability & 83 & 0.99 \\
\hline
\end{tabular}


International Journal of Social Science and Economic Research

ISSN: $2455-8834$

Volume: 05, Issue: 05 "May 2020"

\begin{tabular}{|l|l|l|}
\hline Log percentage returns & 56 & 0.12 \\
\hline
\end{tabular}

Source: Researcher, 2019

The log transformed percentage gain had a Shapiro- W test P Value greater than 0.05 meaning that it was normally distributed.

\subsubsection{Multicollinearity}

In multivariable analysis, the researcher tested for multicollinearity by computing Variance Inflation Factors (VIFs). Values greater than 10 for VIF were considered collinear. The mean VIF was 1.29 showing no multicollinearity.

Table 4.14: Multicollinearity test

\begin{tabular}{|l|l|l|}
\hline Variable & Tolerance & VIF \\
\hline Anchoring & 0.72 & 1.38 \\
\hline Herding & 0.74 & 1.35 \\
\hline Disposition effect & 0.76 & 1.32 \\
\hline Overconfidence & 0.87 & 1.15 \\
\hline Representativeness & 0.79 & 1.26 \\
\hline Availability & 0.68 & 1.48 \\
\hline Age & 0.87 & 1.17 \\
\hline Gender & 0.88 & 1.13 \\
\hline Education & 0.74 & 1.35 \\
\hline Mean VIF & 1.29 & \\
\hline
\end{tabular}

Source: Researcher, 2019

\subsubsection{Heteroscedasticity}

To test for heteroscedasticity, the researcher used Breusch-Pagan/ Cook-Weisberg test with $\mathrm{P}<0.05$ suggesting that the variance is not homogeneous. In all the fitted models, $\mathrm{P}$ was $>0.05$ validating the analyses. Results are as shown in the table below; 
International Journal of Social Science and Economic Research

ISSN: 2455-8834

Volume: 05, Issue: 05 "May 2020"

Table 4.15: Heteroscedasticity test

\begin{tabular}{|l|l|l|l|}
\hline Variable & df1 & df2 & P value \\
\hline Anchoring & 1 & 55 & 0.25 \\
\hline Herding & 1 & 55 & 0.13 \\
\hline Disposition Effect & 1 & 55 & 0.83 \\
\hline Overconfidence & 1 & 55 & 0.65 \\
\hline Representativeness & 1 & 54 & 0.48 \\
\hline Availability & 1 & 54 & 0.35 \\
\hline
\end{tabular}

Source: Researcher, 2019

\subsection{Correlation Analysis}

Correlation was done to establish any relationship and below are the results obtained.

Table 4.16: Correlation coefficients of the variables

\begin{tabular}{|c|c|c|c|c|c|c|c|c|c|c|c|}
\hline & & 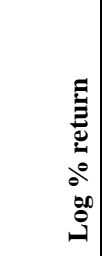 & 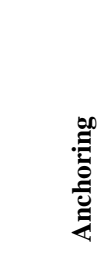 & 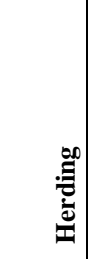 & 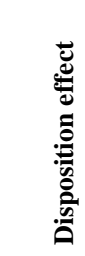 & 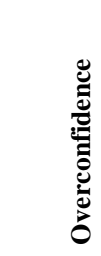 & 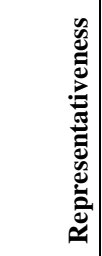 & 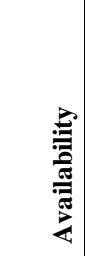 & $\stackrel{\$}{2}$ & 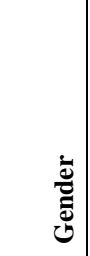 & 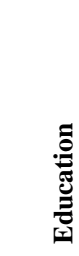 \\
\hline \multirow[t]{3}{*}{ Log \% return } & $\begin{array}{l}\text { Pearson } \\
\text { correlation }\end{array}$ & 1.00 & -0.30 & 0.15 & 0.01 & -0.07 & -0.04 & $\begin{array}{l} \\
0.15\end{array}$ & -0.12 & 0.08 & 0.00 \\
\hline & $P$ value & & 0.03 & 0.27 & 0.94 & 0.61 & 0.75 & 0.27 & 0.37 & 0.55 & 0.99 \\
\hline & $\mathrm{N}$ & 57 & 57 & 56 & 57 & 57 & 56 & 56 & 57 & 57 & 57 \\
\hline \multirow[t]{3}{*}{ Anchoring } & $\begin{array}{l}\text { Pearson } \\
\text { correlation }\end{array}$ & -0.30 & 1.00 & 0.22 & 0.10 & 0.01 & -0.12 & $\begin{array}{l}- \\
0.21\end{array}$ & 0.18 & $\begin{array}{l}- \\
0.08\end{array}$ & $\begin{array}{l}- \\
0.02\end{array}$ \\
\hline & $P$ value & 0.03 & & 0.05 & 0.36 & 0.91 & 0.28 & 0.05 & 0.10 & 0.45 & 0.89 \\
\hline & $\mathrm{N}$ & 57 & 84 & 83 & 84 & 82 & 83 & 83 & 84 & 84 & 84 \\
\hline \multirow[t]{3}{*}{ Herding } & $\begin{array}{l}\text { Pearson } \\
\text { correlation }\end{array}$ & 0.15 & 0.22 & 1.00 & 0.17 & -0.01 & -0.03 & 0.03 & 0.16 & $\begin{array}{l}- \\
0.09 \\
\end{array}$ & 0.07 \\
\hline & $P$ value & 0.27 & 0.05 & & 0.12 & 0.94 & 0.76 & 0.80 & 0.15 & 0.40 & 0.52 \\
\hline & $\mathrm{N}$ & 56 & 83 & 83 & 83 & 81 & 82 & 82 & 83 & 83 & 83 \\
\hline \multirow[t]{3}{*}{$\begin{array}{l}\text { Disposition } \\
\text { effect }\end{array}$} & $\begin{array}{l}\text { Pearson } \\
\text { correlation }\end{array}$ & 0.01 & 0.10 & 0.17 & 1.00 & 0.05 & 0.17 & $\begin{array}{l}- \\
0.08 \\
\end{array}$ & -0.02 & $\begin{array}{l}- \\
0.24 \\
\end{array}$ & $\begin{array}{l}- \\
0.18 \\
\end{array}$ \\
\hline & $\mathrm{P}$ value & 0.94 & 0.36 & 0.12 & & 0.67 & 0.11 & 0.45 & 0.84 & 0.03 & 0.10 \\
\hline & $\mathrm{N}$ & 57 & 84 & 83 & 84 & 82 & 83 & 83 & 84 & 84 & 84 \\
\hline Overconfidence & Pearson & -0.07 & 0.01 & - & 0.05 & 1.00 & 0.09 & - & 0.09 & 0.04 & 0.05 \\
\hline
\end{tabular}


International Journal of Social Science and Economic Research

ISSN: 2455-8834

Volume: 05, Issue: 05 "May 2020"

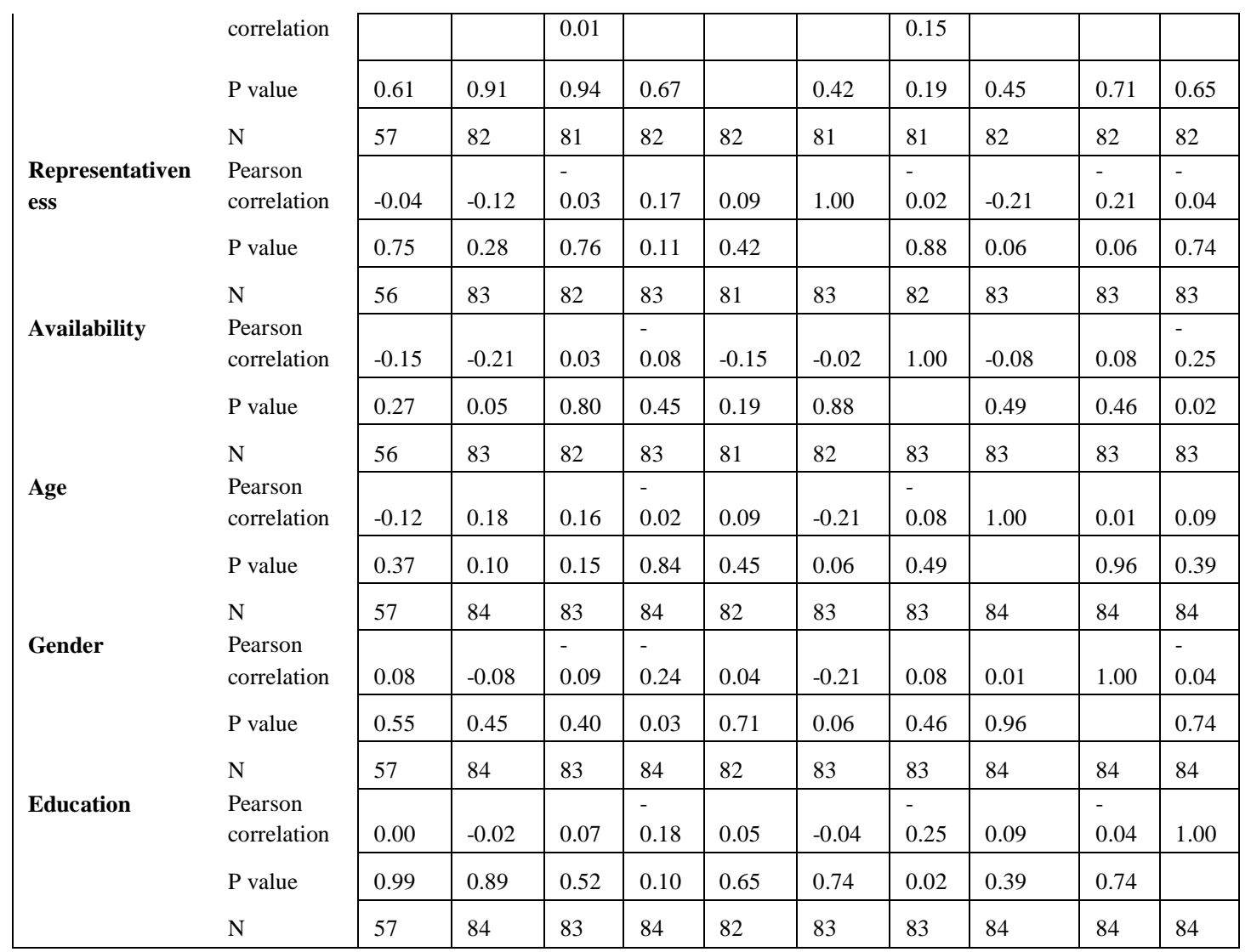

Source: Researcher, 2019

Results indicate there was a significant weak negative correlation between anchoring and investor's percentage returns. $(\mathrm{R}=-0.30, \mathrm{P}=0.03)$. There was a positive but insignificant relationship between percentage returns, herding and gender. Overconfidence, availability, representativeness and age had negative correlation with percentage returns. Education and disposition effect had no relation with returns as their $\mathrm{R}$ was almost zero implying no relationship. The relationship between disposition effect and gender was negative and significantx1, and so was the relationship between availability bias and education.

\subsection{Regression model}

\subsubsection{Regression Analysis}

The researcher used linear regression analyses to establish how behaviour biases affect percentage returns obtained. The regression equation was derived as below;

$\mathrm{Y}=6.836-1.015 \mathrm{X}_{1}+0.522 \mathrm{X}_{2}+0.038 \mathrm{X}_{3}-0.130 \mathrm{X}_{4}-0.032 \mathrm{X}_{5}-0.697 \mathrm{X}_{6}-0.062 \mathrm{X}_{7}+0.338 \mathrm{X}_{8}$ $-0.266 \mathrm{X}_{9}+\varepsilon$ 
International Journal of Social Science and Economic Research

ISSN: $2455-8834$

Volume: 05, Issue: 05 "May 2020"

Table 4.17: Regression Coefficients Table

\begin{tabular}{|l|l|l|l|ll|}
\hline & \multicolumn{2}{|l|}{$\begin{array}{l}\text { Unstandardized } \\
\text { Coefficients }\end{array}$} & $\begin{array}{l}\text { Standardized } \\
\text { Coefficients }\end{array}$ & \multirow{2}{*}{ T } & \multicolumn{1}{c|}{ Sig. } \\
\cline { 2 - 5 } & B & Std Error & Beta & 2.430 & 0.019 \\
& 6.836 & 2.816 & & -3.160 & 0.003 \\
\hline (Constant) & -1.015 & 0.322 & -0.475 & 2.120 & 0.040 \\
\hline Anchoring & 0.522 & 0.247 & 0.314 & 0.130 & 0.897 \\
\hline Herding & 0.038 & 0.292 & 0.019 & -0.540 & 0.595 \\
\hline Disposition & -0.130 & 0.242 & -0.074 & -0.020 & 0.981 \\
\hline Overconfidence & -0.032 & 1.294 & -0.004 & -2.120 & 0.040 \\
\hline Representativeness & -0.697 & 0.329 & -0.330 & -0.260 & 0.794 \\
\hline Availability & -0.697 & -0.036 & 1.010 & 0.319 \\
\hline Age & -0.062 & 0.236 & 0.137 & -0.790 & 0.435 \\
\hline Gender & 0.338 & 0.336 & -0.117 & &
\end{tabular}

Source: Researcher, 2019

Anchoring and availability were found to have negative significant effect on returns. Herding had a positive significant effect on returns with all the other variables having no significance.

\subsubsection{Summary of the model.}

The table below summarises the results of the regression model .

Table 4.18: Summary of the model

\begin{tabular}{|l|l|l|l|}
\hline Model & R & R Squared & Adjusted R Squared \\
\hline 1 & 0.528 & 0.279 & 0.131 \\
\hline
\end{tabular}

Source: Researcher, 2019

As indicated on the model the coefficient of correlation was 0.528 indicating a positive moderate relationship between behavioural biases and investment decisions. $\mathrm{R}^{2}$ results indicate that $27.90 \%$ of changes in returns is explained by behavioural biases. Other changes in returns representing a $72.10 \%$ are explained by factors not accounted for in the model.

\subsubsection{Analysis of Variance}

Table below shows an analysis of the difference in the means. 
International Journal of Social Science and Economic Research

ISSN: 2455-8834

Volume: 05, Issue: 05 "May 2020"

Table 4.19: ANOVA

\begin{tabular}{|l|l|l|}
\hline & F test & Sig. \\
Anchoring & 2.610 & 0.080 \\
Herding & 0.620 & 0.540 \\
Disposition & 0.110 & 0.950 \\
Overconfidence & 0.160 & 0.850 \\
Representativeness & 0.100 & 0.750 \\
Availability & 0.630 & 0.530 \\
\hline
\end{tabular}

Source: Researcher, 2019

The $\mathrm{F}$ test for most of the variables is below one an indication that the variance between the means is not so much.

\subsection{Discussion of findings}

In analysing the effect of behavioural biases on investment decisions; anchoring, availability and herding were found to have an effect on decisions. In terms of tests of significance, the three factors were found to be significant with $\mathrm{P}$ values of 0.03 for anchoring and 0.04 for herding and availability. This implies that investors who referred to some initial information had a significant decrease in returns compared to those who did not refer to an initial piece of information. Investors who followed the actions of their friends had a significant increase in returns compared to those who did not exhibit herding behaviour and those who invested in stocks that readily came to their mind had lower returns. This finding is consistent with the findings of (Waweru, Munyoki, \& Uliana, 2008) who found investors to be affected by herding behaviour. Other behavioural biases; overconfidence, disposition effect and representativeness bias had no significant effect on investment decisions.

The control variables; age, gender and the level of education for the investors had no significant effect on the investor's decisions. Results indicate that as age and level of education increase a decrease in returns was observed. This could mean that as investors age they are not able to keep up with the trends in the market. Results also indicate female investors have better returns compared to male investors. These findings are consistent with the findings of Onsomu et al., (2017) who found investor biases not to be significantly affected by age and level of education. 
International Journal of Social Science and Economic Research

ISSN: 2455-8834

Volume: 05, Issue: 05 "May 2020"

\section{CHAPTER FIVE}

\section{SUMMARY, CONCLUSIONS AND RECOMMENDATIONS}

\subsection{Introduction}

In this chapter a conclusion for the study is offered. A summary of the findings will be presented, recommendations of the study given and any limitations encountered in the study will be outlined. Areas of future research on which other researchers can build up on will also be presented.

\subsection{Summary}

Descriptive research design was used for the study. The study targeted individual investors at NSE as the population for the study. To avoid biased selection of the sample the investors were selected randomly through stockbrokers at NSE. Data were collected by administering questionnaires to individual investors visiting their broker's offices. Data were cleaned up and analyzed using STATA. Before regression, diagnostic tests including; normality tests, multicollinearity and heteroscedasticity were carried out to ensure fitness of the model.

The researcher used regression analysis to explain the relationship between the dependent and independent variable. In terms of demographics, the findings show that most of the investors interviewed were male, majority aged between 26-35 years and most of them having attained at least a Bachelor's degree. Most of the investors were found to make their own decisions with a good number showing overconfidence in their decisions, doing careful analysis of the market and referring to an initial piece of information. Very few investors invested in stocks that their friends and relatives were getting into and very few invested in stocks that they remembered easily.

Anchoring, availability and herding were found to be significant while other biases were found to be insignificant.

\subsection{Conclusion of the study}

This study sought to establish the effect of behavioural biases on investment decisions for individual investors at NSE. The results indicate that, most investors prefer to make their own decisions as they have confidence in their decisions probably due to their vast experience in stocks trading. A good number of the investors carefully analyze the market before investing while very few people are affected by herding behaviour. Many investors were affected by any initial information they had heard regarding particular stocks. 
International Journal of Social Science and Economic Research

ISSN: $2455-8834$

Volume: 05, Issue: 05 "May 2020"

The study also concludes that, anchoring, availability and herding were the only significant behaviours. Other behavioural biases like disposition effect, overconfidence and representativeness were found to be insignificant. Majority of the investors (55.95\%) were aged between 26-35 years and most had at least a Bachelor's degree. This implies an increasing number of youthful people investing at securities market. With the youths having less responsibilities and being enlightened on the importance of investing this is likely to spur economic growth as they invest more and more.

\subsection{Recommendations of the study}

The findings of this study have shown anchoring, availability and herding behaviour significantly affect investment decisions for individual investors at NSE. With the biases found to affect decisions, this study recommends that NSE and CMA organize investor sensitization programmes for both potential and existing investors. This will enable investors to be cognizant of their behaviours that affect the quality of investment choices made. With the information, the investors will be able to improve their performance by avoiding poor decisions they make to their detriment.

Results obtained in this study imply that most of the investors interviewed are between 26-35 years and majority had a first degree. With such results, the study recommends more investment in education by the Government of Kenya. Education seems to be a major driver of economic growth, since; as people become knowledgeable, then they are conscious of opportunities for investing their money. An emphasis on Finance education would be essential to increase the understanding of financial markets.

\subsection{Limitations of the study}

Challenges were faced by the researcher throughout the study period and more so on the data collection. A good number of respondents were apprehensive to give answers to questions concerning their investment amounts and returns as they considered this information confidential. While the returns were to be used to check how investors with behavioural biases differed from those without bias, some respondents were not keen to disclose this information. The dependent variable on investors return was also subjective as it did not look at the bigger portfolio composition.

The researcher also encountered challenges in getting to the investors. While the researcher went through the brokers who were in contact with the investors, some brokers were not keen in getting their clients into answering questionnaires. The researcher constantly assured anonymity and emphasized on the few and simple questions in the questionnaire to ensure minimal time is used. 
International Journal of Social Science and Economic Research

ISSN: $2455-8834$

Volume: 05, Issue: 05 "May 2020"

The study had a time limitation, which limited the possibility of the researcher reaching out to more investors, increasing the target sample, and posing difficulty of finding replacements for the questionnaires that were returned unfilled. While working with a bigger number would mean increased reliability, more resources would be required some of which were not readily available to the researcher.

\subsection{Suggestions for Future Research}

Since this study focused mainly on investors in Nairobi, another study focusing on a broader range of investors from different locations should be carried out to determine if the effect is similar. This will give better understanding of the biases affecting investors and what effect they have on the decisions.

The researcher mainly looked at the effect of behavioural biases on investment decisions while taking into account other control variables. While these factors influence the decisions made, it would be good to look out for several other factors that may explain the investment decisions for investors.

\section{ACKNOWLEGEMENTS}

First, I would like to The Almighty God, for through His mercies I endured the tough journey from coursework to this Project. Thank you God for granting me good health and the wonderful gift of life that I was able to go through this journey peacefully.

To my University Supervisor, Dr Mutunga, thank you so much for your overwhelming guidance and support. You always challenged me to do better in this project. Thank you for your patience, very encouraging words and quick thorough reviews.

A lot of appreciation to all individual investors at NSE who spared their time and assisted in filling out the questionnaires. It would not have been possible without this data from you.

Finally, many thanks to my entire family for your encouraging words and powerful prayers all through this journey. Special appreciation to my husband, John Muriuki for your immense support all through my studies.

\section{REFERENCES}

Adel, B., \& Mariem, T. (2013). The Impact of Overconfidence on Investors ' Decisions. Business and Economic Research, 3(2), 53-75.

Aduda, J., Oduor, O. E., \& Onwonga, M. (2012). The Behaviour and Financial Performance of Individual Investors in the Trading Shares of Companies Listed At the Nairobi Stock Exchange, Kenya. Journal of Finance and Investment Analysis, 1(3), 33-60. 


\section{International Journal of Social Science and Economic Research}

ISSN: $2455-8834$

Volume: 05, Issue: 05 "May 2020"

Arthur, A. (2014). Effect of Behavioural Biases on Investment Decisions of Individual Investors in Kenya. Unpublished MBA Project, University of Nairobi, (November), 97.

Barber, B. M., \& Odean, T. (2013). The Behavior of Individual Investors. In Handbook of the Economics of Finance.

Barberis, N., \& Thaler, R. (2002). A Survey of Behavioral Finance. National Bereau of Economic Research, Working Pa(September).

Bashir, T., AaqibaJaved, Butt, A. A., Azam, N., Tanveer, A., \& Ansar, I. (2013). Factors Influencing the Individual Investor Decision Making Behavior. Journal of Business and Management, 9(5), 37-44.

Bondt, D. F. ., \& Thaler, R. (1985). Does the Stock Market Overreact? The Journal of Finance, 40(3), 793-805.

Chaffai, M., \& Medhioub, I. (2014). Behavioral finance: An empirical study of the Tunisian stock market. International Journal of Economics and Financial Issues, 4(3), 527-538.

Chandra, A. (2009). Individual Investors' Trading Behavior and the Competence Effect. Journal of Behavioral Finance, 6(1), 56-70.

Chen, G., Kim, K. A., Nofsinger, J. R., \& Rui, O. M. (2007). Trading performance, disposition effect, overconfidence, representativeness bias, and experience of emerging market investors. Journal of Behavioral Decision Making, 20, 425-451.

CMA. (2019). Quarterly Statistical Bulletin ( QSB ). In Capital Markets Authority.

Coval, J. D., \& Shumway, T. (2005). Do Behavioral Biases Affect Prices? The Journal of Finance, 60(1), 1-34.

Diecidue, E., \& Somasundaram, J. (2017). Regret theory: A new foundation. Journal of Economic Theory, 172(2017), 88-119.

Fama, E. F. (1970). Efficient Capital Markets: A Review Of Theory And Empirical Work. The Journal of Finance, 25(2), 383-417.

Hayat, A., \& Anwar, M. (2016). Impact of Behavioral Biases on Investment Decision; Moderating Role of Financial Literacy. In Working Paper.

Henderson, V. (2012). Prospect Theory and the Disposition Effect. Management Science, 58(2), $445-460$. 


\section{International Journal of Social Science and Economic Research}

ISSN: $2455-8834$

Volume: 05, Issue: 05 "May 2020"

Kafayat, A. (2014). Interrelationship of biases: effect investment decisions ultimately. Theoritical and Applied Economics, 21(6), 85-110.

Kahneman, D., \& Tversky, A. (1979). Prospect Theory: An Analysis of Decision under Risk. Econometrica, 47(2), 263-292.

Khresna Brahmana, R., Hooy, C., \& Ahmad, Z. (2012). Psychological factors on irrational financial decision making:Case of day of the week anomaly. Humanomics, 28(4), 236257.

Kimeu, C. N., Anyango, W., \& Rotich, G. (2016). Behavioural Factors Influencing Investment Decisions Among Individual Investors in Nairobi Securities Exchange. The Strategic Journal of Business \& Change Management, 3(4), 1243-1258.

Lichtenstein, S., \& Slovic, P. (1970). Reversals of Preference Between Bids and Choices in Gambling Decisions. Research Bulletin, 10(7), 1-30.

Loomes, G., \& Sugden, R. (1982). Regret Theory: An Alternative Theory of Rational Choice Under Uncertainty. The Economic Journal, 92(368), 805-824.

Lux, T. (1995). Herd Behaviour, Bubbles and Crashes. The Economic Journal, 105(431), 881.

Mahina, J. N., Muturi, W., \& Florence, M. (2017). Effect of Behavioural Biases on Investments at the Rwanda Stock Exchange. International Journal of Accounting, Finance and Risk Management, 2(4), 131-137.

Markowitz, H. (1952). Portfolio selection. The Journal of Finance, 7(1), 77-91.

Mongin, P. (1997). Expected utility theory. In Handbook of Economic Methodology.

Neumann, John von, \& Morgenstern, Oskar. (1947). Theory of Games and Economic Behavior. In Princeton University Press.

Nyamute, W. I. (2016). Investor Behaviour , Investor Demographic Characteristics , Ivestment Style and Individual Investor Portfolio Perfomance at the Nairobi Securities Exchange. Unpublished Thesis, Jomo Kenyatta University of Agriculture and Technology.

Odean, T. (1998). Volume, Volatility, Price, and Profit When All Traders Are Above Average. The Journal of Finance, 53(6), 1887-1934.

Onsomu, Z. N., Kaijage, P. E., Aduda, J., \& Iraya, C. (2017a). Risk Tolerance , Demographics and Portfolio Performance. Journal of Business and Economic Policy, 4(3), 69-74. 
International Journal of Social Science and Economic Research

ISSN: 2455-8834

Volume: 05, Issue: 05 "May 2020"

Onsomu, Z. N., Kaijage, P. E., Aduda, P. J., \& Iraya, C. (2017b). Demographics and Investor Biases At the Nairobi Securities Exchange, Kenya. Interntional Journal of Arts and Commerce, 6(5), 51-60.

Sanglier, M., Romain, M., \& Flament, F. (1994). A behavioral approach of the dynamics of financial markets. Decision Support Systems, 12(1994), 405-413.

Schmeidler, D. (1984). Subjective Probability and Expected Utility without Additivity. In IMA Preprint Series (Vol. 84).

Shefrin, H., \& Statman, M. (1985). The Disposition to Sell Winners Too Early and Ride Losers Too Long: Theory and Evidence. The Journal of Finance, 40(3), 777-790.

Shefrin, H., \& Statman, M. (2000). Behavioural Portfolio Theory. Journal of Financial and Quantitative Analysis, 35(2), 127-151.

Shiller, R. J. (2003). From Efficient Markets Theory to Behavioral Finance. Journal of Economic Perspectives, 17(1), 83-104.

Shunmugathangam, P. (2017). Investment Decision Making for Small Individual Investors - a Study With Special Reference To Tirunelveli District. International Research Journal of Engineering and Technology, 4(11), 1257-1261.

Toma, F.-M. (2015). Behavioral Biases of the Investment Decisions of Romanian Investorson the Bucharest Stock Exchange. Procedia Economics and Finance, 32(2015), 200-207.

Tversky, A., \& Kahneman, D. (1974). Judgment under Uncertainty: Heuristics and Biases. Science, 185(4157), 1124-1131.

Virigineni, M., \& Rao, M. B. (2017). Contemporary Developments in Behavioral Finance. International Journal of Economics and Financial Issues, 7(1), 448-459.

Virlics, A. (2013). Investment Decision Making and Risk. Procedia Economics and Finance, 6(2013), 169-177.

Waweru, N. M., Munyoki, E., \& Uliana, E. (2008). The Effects of Behavioural Factors in Investment Decision-making: A Survey of Institutional Investors Operating at the Nairobi Stock Exchange. International Journal of Business and Emerging Markets, 1(1), $24-41$. 